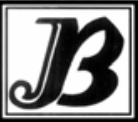

J. bio-sci. 14: 83-86, 2006

ISSN 1023-8654

\title{
PHYSICO-CHEMICAL COMPOSITION OF FOUR PAPAYA VARIETIES GROWN AT RAJSHAHI
}

\author{
W Zaman ${ }^{1}$, S K Biswas ${ }^{1 *}$, M 0 H Helali'1, M Ibrahim ${ }^{1}$ and Parvez Hassan ${ }^{2}$ \\ ${ }^{1}$ Fruits and Food Processing and Preservation Research Division \\ BCSIR Laboratories, Rajshahi. \\ 2 Institute of Biological Sciences, University of Rajshahi, \\ Rajshahi -6205, Bangladesh.
}

\begin{abstract}
A study was carried out on four papaya varieties namely, Bombai, Deshi, Shahi (Yellow) and Shahi (Red) for their physico-chemical composition grown at Rajshahi. The results showed that maximum fruit weight was observed in Bombai and lowest in Shahi (Red). It was also found that recovery of pulp, TSS and total sugar were $80.46-87.41 \%, 9.0-13.0 \%$ and $6.96-10.50 \%$ respectively.
\end{abstract}

Key words: Papaya, physical composition and chemical composition.

\section{Introduction}

Bangladesh produces a huge quantity of fruits annually. Papaya (Carica papaya) is also an important fruit grown almost throughout Bangladesh. The production of papaya at Rajshahi is famous for its growth and fruiting. Physico-chemical characteristics are the important qualitative indexes of any fruit for fresh consumption. Total soluble solid determines the quantity of pulp and other canned products. The information regarding the physico-chemical composition of papaya is not known. Keeping this view in mind, the present investigation was undertaken.

\section{Materials and Methods}

\section{Raw Material}

Four varieties of papaya namely, Bombai, Deshi, Shahi (Yellow) and Shahi (Red) were collected from the local areas and were used in the experiments.

\section{Methods}

The mean observations of Five of each variety fruit were recorded on the fruit weight, diameter, length, pulp(edible portion) and seed and skin-weight (non-edible portion) of the fruits. The pulp percentage was also calculated on the basis of total fruit weight. $\mathrm{pH}$ was measured using a digital $\mathrm{pH}$ meter. Total soluble solids (TSS) were recorded by hand refractometer. Acidity was determined by titration method (AOAC 1975) and the results expressed as percentage of citric acid. Vitamin $C$ was estimated by the visual titration method

\footnotetext{
* To whom all correspondence should be addressed.
} 
using 2,6, dichlorophenol indophenol dye (Gyorgy and Pearson 1967). Total sugars and reducing sugars were determined from the detailed procedures as described in Lane- Eynon method (Ranganna 1986).

\section{Results and Discussion}

The fruits of the four papaya varieties differed in respect to their physical and chemical characteristics. Fruit weight of the different papaya varieties varied from 645.40 to $1740.00 \mathrm{gm}$ (Table 1). The highest fruit weight was recorded in Bombai and the lowest in Shahi (Red). Among the varieties, the diameter of the fruit was maximum in Bombai followed by Deshi and Shahi (Yellow). As regards to length, it was maximum in Bombai $(25 \mathrm{~cm})$ followed by Shahi $($ Red).

Pulp is the edible portion of the fruit and the variety Bombai had the highest mean pulp weight (1400.00gm) while it was lowest in Shahi (Red) variety. Highest pulp percentage (87.41\%) was recorded in Shahi (Yellow) and lowest in Bombai $(80.46 \%)$. The highest portion of seed was produced by Bombai (6.90\%).

Skin is the non-edible waste portion of the fruit. Lower the quantities of skin better will be the quantity of fruit. Shahi (Yellow) variety contained the lowest quantity of skin (12.15\%). Similar quantity of skin was recorded in Bombai and Shahi (Red).

Table 1. Analyzed physical parameters of four varieties of papaya.

\begin{tabular}{|c|c|c|c|c|c|c|c|c|c|}
\hline \multirow{2}{*}{$\begin{array}{l}\text { Name } \\
\text { of the } \\
\text { variety }\end{array}$} & \multirow{2}{*}{$\begin{array}{c}\text { Fruit } \\
\text { weight } \\
(\mathrm{gm})\end{array}$} & \multicolumn{2}{|c|}{ Fruit size } & \multicolumn{2}{|c|}{ Edible portion } & \multicolumn{4}{|c|}{ Non-edible portion } \\
\hline & & $\begin{array}{c}\text { Diameter } \\
\text { (cm) }\end{array}$ & $\begin{array}{l}\text { Length } \\
(\mathrm{cm})\end{array}$ & $\begin{array}{l}\text { Pulp wt. } \\
\text { (gm) }\end{array}$ & $\begin{array}{l}\text { pulp } \\
(\%)\end{array}$ & $\begin{array}{l}\text { Seed wt. } \\
\text { (gm) }\end{array}$ & $\begin{array}{c}\text { Seed } \\
(\%)\end{array}$ & $\begin{array}{l}\text { Skin wt. } \\
\text { (gm) }\end{array}$ & $\begin{array}{l}\text { Skin } \\
(\%)\end{array}$ \\
\hline 1 & 2 & 3 & 4 & 5 & 6 & 7 & 8 & 9 & 10 \\
\hline Bombai & $\begin{array}{r}1740 \pm \\
0.415\end{array}$ & $\begin{array}{l}4.4 \pm \\
0.017\end{array}$ & $\begin{array}{c}25.0 \pm \\
0.24\end{array}$ & $\begin{array}{l}1400.00 \\
\pm 0.537\end{array}$ & $\begin{array}{c}80.46 \pm \\
.208\end{array}$ & $\begin{array}{l}120 \\
. \pm \\
0.125\end{array}$ & $\begin{array}{l}6.90 \pm \\
0.002\end{array}$ & $\begin{array}{r}220.00 \pm \\
0.325\end{array}$ & $\begin{array}{r}12.64 \pm \\
0.04\end{array}$ \\
\hline Deshi & $\begin{array}{c}709.80 \\
\pm \\
0.355\end{array}$ & $\begin{array}{l}3.8 \pm \\
0.002\end{array}$ & $\begin{array}{c}20.0 \pm \\
0.22\end{array}$ & $\begin{array}{r}600.00 \\
\pm 0.380\end{array}$ & $\begin{array}{c}84.53 \pm \\
0.284\end{array}$ & $\begin{array}{l}7.80 \pm \\
0.021\end{array}$ & $\begin{array}{l}1.10 \pm \\
0.001\end{array}$ & $\begin{array}{c}102.00 \pm \\
0.223\end{array}$ & $\begin{array}{c}14.37 \pm \\
0.12\end{array}$ \\
\hline $\begin{array}{l}\text { Shahi } \\
\text { (Yellow) }\end{array}$ & $\begin{array}{c}686.40 \\
\pm \\
0.358\end{array}$ & $\begin{array}{l}3.8 \pm \\
0.003\end{array}$ & $\begin{array}{c}19.0 \\
\pm \\
0.02\end{array}$ & $\begin{array}{c}600.00 \\
\pm \\
0.374\end{array}$ & $\begin{array}{c}87.41 \pm \\
0.123\end{array}$ & $\begin{array}{l}3.00 \pm \\
0.015\end{array}$ & $\begin{array}{l}0.44 \pm \\
.0004\end{array}$ & $\begin{array}{c}83.40 \pm \\
0.127\end{array}$ & $\begin{array}{c}12.15 \pm \\
0.15\end{array}$ \\
\hline $\begin{array}{l}\text { Shahi } \\
\text { (Red) }\end{array}$ & $\begin{array}{c}645.40 \\
\pm \\
0.046\end{array}$ & $\begin{array}{l}3.7 \pm \\
0.002\end{array}$ & $\begin{array}{l}20.5 \pm \\
0.025\end{array}$ & $\begin{array}{c}550.00 \\
\pm \\
0.245\end{array}$ & $\begin{array}{c}85.22 \pm \\
0.240\end{array}$ & $\begin{array}{c}16.20 \pm \\
0.140\end{array}$ & $\begin{array}{l}2.51 \pm \\
0.0016\end{array}$ & $\begin{array}{c}79.20 \pm \\
0.115\end{array}$ & $\begin{array}{c}12.27 \pm \\
0.17\end{array}$ \\
\hline
\end{tabular}

Values are mean \pm standard error (S.E.).

From data presented in Table 2, it is observed that chemical composition of papaya varieties differed significantly. $\mathrm{pH}$ of papaya fruits varied from 4.2-4.5. TSS (Total soluble solid) judges the qualitative characters of a fruit. The total soluble solids varied from 9.0 to $13.0 \%$ in different varieties. The total soluble 
solids were the highest in the fruit pulp of Bombai followed by Deshi and Shahi (Yellow). Lowest total soluble solids were recorded in the pulp of Shahi (Red). Among the variety studied, the acidity (as citric acid) ranged between 2.00 to $2.30 \%$ being highest in Bombai fruit pulp and lowest in Shahi (Red). The range of Vitamin C content was 41.0 to $42.40 \mathrm{mg} / 100 \mathrm{gm}$ of pulp. Vitamin C content was higher in the variety Bombai $42.40 \mathrm{mg} / 100 \mathrm{gm}$ followed by Shahi (Yellow) - $42.00 \mathrm{mg} / 100 \mathrm{gm}$, Shahi (Red) $-41.60 \mathrm{mg} / 100 \mathrm{gm}$ and Deshi$41.00 \mathrm{mg} / 100 \mathrm{gm}$. Total sugar content varied from 6.96 to $10.50 \%$ and reducing sugar content ranged from 3.42 to $6.92 \%$. Non-reducing sugar was higher in the variety Bombai (3.58\%) and lowest in Deshi (3.17\%).

Table 2. Analyzed Chemical parameters of four papaya varieties.

\begin{tabular}{|c|c|c|c|c|c|c|c|}
\hline $\begin{array}{l}\text { Name } \\
\text { of variety }\end{array}$ & $\mathrm{pH}$ & $\begin{array}{l}\text { TSS } \\
(\%)\end{array}$ & $\begin{array}{c}\text { Acidity } \\
\text { as citric acid } \\
(\%)\end{array}$ & $\begin{array}{l}\text { Vitamin C } \\
(\mathrm{mg} / 100 \mathrm{gm})\end{array}$ & $\begin{array}{c}\text { Total sugar } \\
(\%)\end{array}$ & $\begin{array}{c}\text { Reducing } \\
\text { sugar } \\
(\%)\end{array}$ & $\begin{array}{c}\text { Non-reducing } \\
\text { sugar } \\
(\%)\end{array}$ \\
\hline Bombai & $\begin{array}{c}4.4 \\
\pm 0.015\end{array}$ & $\begin{array}{l}13.0 \pm \\
0.045\end{array}$ & $\begin{array}{l}2.30 \pm \\
0.007\end{array}$ & $\begin{array}{c}42.40 \pm \\
0.178\end{array}$ & $\begin{array}{l}10.50 \pm \\
0.0093\end{array}$ & $\begin{array}{l}6.92 \pm \\
0.0038\end{array}$ & $\begin{array}{l}3.58 \pm \\
0.0015\end{array}$ \\
\hline Deshi & $\begin{array}{l}4.3 \pm \\
0.011\end{array}$ & $\begin{array}{l}12.0 \pm \\
0.011\end{array}$ & $\begin{array}{l}2.10 \pm \\
0.014\end{array}$ & $\begin{array}{l}41.00 \pm \\
0.0115\end{array}$ & $\begin{array}{l}8.85 \pm \\
0.0007\end{array}$ & $\begin{array}{l}5.68 \pm \\
0.0011\end{array}$ & $\begin{array}{l}3.17 \pm \\
0.0012\end{array}$ \\
\hline $\begin{array}{l}\text { Shahi } \\
\text { (Yellow) }\end{array}$ & $\begin{array}{l}4.5 \pm \\
0.008\end{array}$ & $\begin{array}{l}11.0 \pm \\
0.015\end{array}$ & $\begin{array}{l}2.20 \pm \\
0.006\end{array}$ & $\begin{array}{l}42.00 \pm \\
0.0055\end{array}$ & $\begin{array}{l}7.68 \pm \\
0.0006\end{array}$ & $\begin{array}{l}4.20 \pm \\
0.0047\end{array}$ & $\begin{array}{l}3.48 \pm \\
0.038\end{array}$ \\
\hline $\begin{array}{l}\text { Shahi } \\
\text { (Red) }\end{array}$ & $\begin{array}{l}4.2 \pm \\
0.011\end{array}$ & $\begin{array}{l}9.0 \pm \\
0.047\end{array}$ & $\begin{array}{l}2.00 \pm \\
0.038\end{array}$ & $\begin{array}{l}41.60 \pm \\
0.0148\end{array}$ & $\begin{array}{l}6.96 \pm \\
0.001\end{array}$ & $\begin{array}{l}3.42 \pm \\
0.006\end{array}$ & $\begin{array}{l}3.54 \pm \\
0.011\end{array}$ \\
\hline
\end{tabular}

Values are mean \pm standard error (S.E.).

From the above findings, it is evident that the physico-chemical parameters of papaya varieties differed from one another which are supposed to be due to different genetic make up the variety and also because of the difference in their total fruit development and ripening period (Handbook of Agriculture 1961 and Selvaraj et al. 1982). The differences in physico-chemical composition of different papaya varieties are in agreement with the findings of the workers (Chan et al. 1971, Pal et al. 1980 and Selvaraj et al. 1982). However, the present study indicates that the fruits of Bombai, Deshi and Shahi (Yellow) may be acceptable for table purposes, canning and for various drinks and product making.

\section{Acknowledgements}

The authors are thankful to Director-in-Charge, BCSIR Laboratories, Rajshahi, Rajshahi, Bangladesh for providing facilities for the experiments. 


\section{References}

AOAC (1975) Association of Official Analytical Chemists. Official Methods of Analysis, Washington DC $12^{\text {th }}$ ed. p.283.

Chan HT, Chang TSK, Stafford AE and Brekke JE (1971) Nonvolatile acids of papaya. J. Agric. Food Chem. 19 (2): 263-265.

Gyorgy P and Pearson W N (1967) The Vitamins. $2^{\text {nd }}$ ed. Academic Press, New York. U S A. p. 32.

Handbook of Agriculture (1961) ICAR, New Delhi, India. p.123.

Pal DK, Subramanyam MD, Divakar NG, lyer CPA and Selvaraj Y (1980) Studies on the physico-chemical composition of fruits of twelve papaya varieties. J. Food Sci. Technol. 17: 254-256.

Ranganna S (1986) Handbook of Analysis and Quality Control for Fruit and Vegetable Products. $2^{\text {nd }}$ ed. Tata McGraw Hill Publishing Company Ltd., New Delhi, India. p.12.

Selvaraj Y, Subramanyam M D and lyer C P A (1982) Changes in the chemical composition of four cultivars of papaya (Carica papaya L.) during growth and development. J. Hort. Sci. London. 57: 135-143. 